\title{
Classifying Divided Cities: the Need for Geopolitical Perspective?
}

\author{
Marta Zorko \\ University of Zagreb, Faculty of Political Science, Croatia \\ e-mail:mzorkofpzg@gmail.com
}

\section{Nikola Novak}

University Institute of Lisbon (ISCTE-IUL), Centre for International Studies, Portugal

e-mail:nnkai@iscte-iul.pt

\begin{abstract}
Divided cities are common phenomena in contemporary world. Each case is driven out of a different set of factors and consists of different manifestations of divisions. This paper seeks to identify the categorization of divisions and offer the criteria that should be considered when researching the phenomenon of divided cities. The geopolitical perspective may serve as a tool for overcoming the confusion in different sets of classifications. The authors suggest four sets of criteria within which divided cities have to be considered when rethinking a geopolitical perspective on this issue. Divided cities are an empirical state of fact and appear across the Globe. Moreover, most of world cities are somehow divided, but cannot be called divided cities in geopolitical terms. This paper shows the differences in divisions taking into account geographical, political, identity and power relations bringing them into a geopolitical set of related criteria.
\end{abstract}

Key words: micro-geopolitics, divided cities, border studies, reterritorialization.

\section{Introduction: State of Art and Divided Cities}

There are different lists of divided cities, as well as different case studies on manifestations of divisions. Nevertheless, the classification of criteria taken into account varies across sub-disciplines in social sciences. In the perspective of sociology, the themes of segregation, inclusion and exclusion of the society were primarily present in the work of authors in this field. Michney's (2014) global history of segregation is only one example. Nevertheless, some authors were focused on different case studies, gender or age group. Madeleine Leonard, for instance, explored the ways in which teenagers occupy and manage space in one divided community in 
Northern Ireland - "drawing on stories, maps and focus group discussions with 80 teenagers, from an interface area in Belfast, the article reveals their perceptions and experiences of divided cities, as risky landscapes" (2010:329). When researching divided cities and divided societies, it is hard not to include the notions of people's behaviour. Nevertheless, state of art in the area of psychology and anthropology has been lagged. Low (1996) analyzed anthropological literature from 1989 onwards, in relation to urban theory.

She concluded that city in general is not absent from anthropological studies, but it has been neglected. Furthermore, "the images of the ethnic city, divided city, deindustrialized city, and global city have been most influential, as has research in the areas of racism, migration, post-structural studies of conflict and resistance, and critiques of architecture and urban planning" (Low, 1996:383). In divided cities, it is hard to separate society from the space and time. Therefore, human geography and global history is often included in the analysis of divided cities, divided societies and urban conflicts. For example, in South Africa non-whites' and whites' groups of inhabitants were not only divided legally, by issuing laws dealing with segregation, but they also went a few steps forward by creating "a spatial segregation based on well-defined land allocation policy and by using physical features such as rivers, roads and railways to demarcate the segregated territories" (Kliot and Mansfeld 1999:170). According to mainstream urban geography, "this is basically a problem, which results from hierarchy of power and wealth in which those in political and economic control decide and others are decided for" (Kliot and Mansfeld, 1999: 167). On the contrary, architecture and urban design focus more on spatial factors in the context of life planning. They prefer policy to politics. There is evidence that explains that even urban planning (or non-planning) could influence divisions in the cities. Merely innocent development of new materials in Sao Paulo divided the city into secure and insecure zones, based on the difference in wealth (Ohtake, 2008).

Holt-Jensen (2008) connects three other concepts in urban theories with possible divisions in city structures: the concept of global city; the concept of dual city; and social polarization. And whilst Saskia Sassen (1991) introduced global cities as power generating entities larger than even national states, Manuel Castells' (1989:343) anticipated "increasing labour differentiation and 'new urban dualism' set forward the conclusion that the global city is also the dual city. Sassen (1991) came to the same conclusion, but introduced the term 'social polarization' as a strong signifier" (Holt-Jensen, 2008:118). Nevertheless, both interpretations consist of dualism in wealth, power and development on micro- scale level and rely on the ideological background that could be found both in neo-liberalism and neo-Marxist theories.

Historical perspective narrows its interests in state of art towards historical manifestations of divided cities. Berlin during the Cold War (Elkins and Hofmeister, 2005; Broatbend and Hake, 2010), English cities in the Colonial times (Miller, 2007) or divided state-cities during Ancient times are some of the examples (Loreaux, 2006). To some extent, the history of divided cities is the history of violence and conflict. 
Peace and conflict studies focus on reasons of conflicts in divided societies, ethnonational frictions and the peace-building process. O'Dowd and McKnight (2013) elaborated the connection of religion and violence on micro-regional levels, Oberschall (2007) analyzed divided societies trough case studies of Bosnia /Bosnia and Herzegovina/, the Israel-Palestine conflict and Northern Ireland, while O'Flynn (2006) and Guelke (2004) considered the possibility of influence of democratization in practical terms. Eight forms of urban conflict by Gaffkin and Morrisey (2011) are consistent with the factors that drive the change in contemporary cities towards splits and divisions on the global level. The first set includes a "bifurcation of labor market, and a related acute socio-spatial segregation between rich and poor. In its starkest form, the flourishing gated communities of the wealthy and the languishing ghettos of the underclass are deemed to constitute a dual or two-speed city that is inherently unstable and prone to conflict" (Gaffkin and Morrisey, 2011:19).

The second form is related to similar frictions between rich and poor but on the global scale, namely in the Global South, where speed and uncontrolled urbanization present potential risk for divisions and violence. The third one relates to the uprise of migration processes due to the globalization processes and the already mentioned forms of inequality (ibid.). One may add ghettoization in suburbs or camps in destination countries as well. Authors (ibid.) argue that "new demographic configuration brings greater ethnic and religious diversity to even formerly homogeneous societies, and since the new populations tend to congregate in kindred city communities, the urban has become a concentrated arena that tests humanity's ability to live peaceably with difference". The fourth form tassels with Huntington's notions about the Clash of Civilizations. Identity, religion and civilization form curved enemy lines, "particularly the major fault line that involves elements of Islam and their perceived enemies. While producing new macro-geographies, such as the provocatively designated 'axis of evil', this absolutist confrontation also hardens ancient enmities in specific cities like Jerusalem and Beirut, and sparks newer ones in cities like Baghdad" (Gaffkin and Morrisey, 2011:19).

The authors argue that the new fights of the future will consist of urban battlefields in war zones as the fifth form in their analysis. The sixth one is related to historical drivers of frictions, namely the international community (in the case of Berlin), and governing (in the case of South Africa), while the next one includes future challenges in a form of intensified climate changes and its consequences. "Such global contests will come to ground most acutely in specific cities, and the racial profile of the forsaken in New Orleans in the aftermath of Hurricane Katrina illustrates the politically toxic capacity of such catastrophes" (Gaffkin and Morrisey, 2011:20).

Finally, authors argue that the end of the Cold War era influenced the rise of some embedded frictions, frozen under authoritarian and centralist regimes, "old ethnic animosities and ushered in a new wave of ethno-nationalist contest. These new arenas of dispute about borders and sovereignty, such as the Balkans and Chechnya, join those nationalist cauldrons of more longstanding, such as the major conflicts of Israel-Palestine, Lebanon, and Kashmir-India-Pakistan, and those less significant geopolitically, such as Cyprus, Northern Ireland, and the Basque Country. There is 
a tendency for such macro quarrels to find most ferocious expression in the main urban centers, such as Jerusalem, Beirut, Sarajevo, Grozny, Nicosia, Belfast, and Bilbao" (Gaffkin and Morrisey, 2011:20).

Bearing in mind the complex nature of the phenomenon of divided cities, interdisciplinary approach might seem the most suitable one since different disciplines intertwine in its nature. For instance, Bollens refers to psycho-geographies of "the soul's memory layers" (2011:17) while analyzing the possibilities of transformation of divided societies. As memory layers influence divided societies, mental and imagined borders often frame divided cities.

\section{The need for Geopolitical Perspective}

Although classical geopolitics focused primarily on the state and its benefits, critical geopolitics acknowledges the existence of new macro and micro regional actors. Nevertheless, Jonas and Moisio (2018:351) in setting their approach of city regions as a new kind of global phenomenon "conceptualize the state as a constant geopolitical process to territorialize political power/authority through a great variety of governmental technologies ranging from spatial planning and public administration to economic development and education". That means that even in contemporary environment, state plays a major role on micro-regional levels as well. State power may be used in construction and deconstruction as well. As they notice that "by means of its concrete powers and functions (e.g. administrative, electoral, technocratic, etc.), the national state increasingly mediates and orchestrates accumulation around city regions as part of more general efforts to secure economic growth, to generate competitive advantages for factions of capital, and to ensure societal order within its territorial jurisdictions" (Jonas and Moisio, 2018:351). Therefore, as it may influence the accumulation of power and prosperity, it can enhance divisions in divided cities as well - both by doing and non-doing.

The geopolitical perspective frames the interdisciplinary view of social sciences in its core. The three geopolitical pillars - territory, people and power - set the key criteria for rethinking divided cities in both interdisciplinary and geopolitical contexts. Critical geopolitics enabled wider thinking and divided geopolitics into a formal, practical, popular and structural sub-discipline (O Tuathail, 1999:110). Each of them might deal with divided cities from their own perspective. For instance, formal geopolitics explains how divisions were perceived in the classical context in the works of traditional great thinkers. Practical geopolitics, oriented towards everyday practice in politics explains how divisions may intervene with ordinary people and policy practice. Popular geopolitics explores the way some phenomenon is represented in popular culture products, while structural geopolitics tries to explain global processes and their local representations. Since "geopolitics can be described as problem-solving theory for the conceptualization and practice of statecraft" ( $O$ Tuathail, 2013:107), it is a useful tool for micro-related divisions of power in divided cities and divided societies. Even more, critical geopolitics "is a problematizing theoretical enterprise that places the existing structures of power and knowledge in 
question" (O Tuathail, 2013:107). That is why structural perspective, both in creation and deconstruction of different divisions, plays a major role in this analysis.

Nevertheless, even in geopolitical studies there is inconsistence regarding the classification of divisions. The notion of division seems to be used and misused when elaborating the reasons and background in some cases. This paper seeks to establish a set of criteria taking into account all the aspects of different divisions. The geopolitical perspective of four criteria will be further elaborated. In their research about political geographies of urban polarization, Allegra, Casaglia and Rokem, suggest that "instead of creating separate categories of cities and then trying to make room for deviant or ambiguous cases, we should identify significant drives of spatial polarization and then determine how and to what extent they operate and interact in each specific urban context" (2012:561). Their idea reflects the ability of three main areas or functions of urban governance - polity, politics and policy - to be understood as the political drives of urban fragmentation. In this way, these drivers are interconnected, and spatial polarization is the result of the interaction of the three drives. This makes every divided city a unique case study, while, at the same time, "all cities can be relevant in illuminating more general patterns of urbanism" (Allegra et al. 2012:569). The findings of this research, thus, appoint a necessity for tools and concepts to connect existing research studies of divided cities and, consequently, create a set of criteria. These criteria are a derivation of general premises based on specific observations of phenomena in focus of this research.

When thinking about cities in general, all could be divided by some form of division, but that does not make them divided cities. The view of Gaffkin and Morrisey (2011:21) is that "all cities in the contemporary world are in some regard 'divided cities'. Thus, it is important to make a differentiation about the type of division". The authors selected two main types, the first is the one "concerns those disputes, which are predominantly about pluralist issues of social class, status, power and equity, and the second concerns how macro disputes about state sovereignty become encapsulated most acutely in micro spaces in the main cities of the territories involved" (Gaffkin and Morrisey, 2011:21). Van Kempen (2007:15) argues that "the undivided city is a myth and a utopia at the same time". However, not every city should be called divided. Numerous classifications show that each case study is unique, but there are similar criteria that should be taken into consideration.

A river that separates cities in two halves, avenues, different urbanistic solutions or even the difference between old and new town could be called divisions, but that does not make a city divided in its core. Fore example, Budapest and Istanbul are divided by separate settlements or even different continents, but are not divided in geopolitical terms. Some cities were divided in the past by physical obstacles, but even that did not make them divided. For instance, Berlin is an example of an artificially divided city with a unified soul. There are numerous cities divided not only by a river, but by an international border as well. However, they should be referred to as twin cities and not divided ones. Although, some of the border cities could be divided as well, they cannot be regarded in the same category as divided cities located within a specific nation-state border. Similar to these findings, enclaves and exclaves could not 
be included in this classification. Some lists of divided cities include divided regions and different enclaves and exclaves, but those entities do not have sufficient common variables to be defined by solely the notion of divided cities in geopolitical terms.

Gaffkin and Morrisey suggest, "whatever the difference in context and form, urban conflicts share a linked set of issues: history, identity, territory, propinquity, legitimacy, equity, and security" (2011:20). Therefore they create four frameworks for the analysis: "The political (addressing the basis of legitimacy, and including arguments about governance and about whether pluralist democracy offers the most effective instrument for securing consensus and compromise between protagonists); The economic (examining the material basis for class and power inequities, seen to underpin the fissures); The cultural (emphasizing the way rival norms, traditions, and claims of ethnic groups determine mutual antagonism, ranging from estrangement to active hostility); The spatial (the relational geographies that attend the conflict)" (Gaffkin and Morrisey, 2011:21).

\section{The basis for geopolitical classification of Divided cities}

\subsection{The visibility of division}

The first criterion in the context of geopolitical aspects of divided cities refers to the empirical ability of researchers to note that a city is physically divided. Nevertheless, there could be cities with no physical evidence of divisions, yet divided mentally in its inhabitants' minds. Physical obstacles may vary from artificial ones, namely, wall, wire, logs, concrete blocks, all the way to the natural geographic obstacles or no man's land. Mental borders also may vary, but they often go along some historical or identity artifacts. In that way, some locations may gain new meaning as a mental border. For instance, streets that used to form war lines in the past, ghettos, building blocks, new and old bridges, etc.

Boundaries of division could be straight or curved, in a form of boundary or even a frontier. Fluid borders in a form of frontier could be found in between two locations of a great significance for different sides and perspectives. Namely, self-perception of population within certain divided city may vary in correlation with personal selfidentification. The research conducted in the city of Mostar in Bosnia-Herzegovina proved mental division in a form of frontier that goes from former war line (street) to the Neretva River (Zorko and Novak, 2017).

\subsection{The critical juncture}

The second criterion relates to power games and internal relations that could lead to conflict potential. In that sense, the critical juncture presents a point in history after which division occurred. This means that the source of division in a specific city reflects a chain of events that established the city as divided. Namely, the second 
criterion encompasses all relations in micro-geopolitical community that are based on power. Power itself represents a dominant virtue that shapes the constellation of relations in these communities. Specific fractions within inhabitants of divided cities provoke ruptures by using power games that result in conflicts, disagreements or violence. The final outcomes of these ruptures are visible in some means of divisions.

Fractions isolate themselves in order to compensate their lack of power over other fractions. Lack of political dialogue causes ghettoization, separation and complete ignorance of inhabitants that are not part of the same fraction within the city. If the critical juncture is provoked by the on-going violence, the city is de facto divided. In case there is a political agreement or treaty that officially manages violence, it leads to de jure division of the city. The example for the latter is the Cyprus capital Nicosia or Jerusalem in Israel. Both cities are divided officially between ethnical fractions engaged in conflict. The mentioned examples fit into the classification since both The Turkish Republic of Northern Cyprus and Palestine are not internationally recognized as sovereign states.

\subsection{The division of social environment}

Divisions in social environment mean an identity belonging or non-belonging to a group of people. Those identity belongings could be based on nationality, ethnicity, race, class and/or religion. Identity in this sense presumes self-image and personal self-relation towards one or the other fraction in a divided city. This means that ghettoization or separation in divided cities happens because members of different fractions see their identity as superior to other existing identities. Exclusiveness in self-identifications of fractions in divided cities seeks to accomplish dominance of one fraction over another.

Narratives and myths are components of geopolitical culture of each and every state (O Tuathail et al. 2007). If researching micro-geopolitical entities such as cities, urban myths and legends frame narratives and stories that enhance identity belonging. The geopolitical discourse of Jerusalem, as the capital of the world religions' territorialized division of holy places, perpetuates the division of the city even further. Moreover, Hercbergs and Noy (2015) show how these discourses could be engaged in global geopolitical visions of division. Such narratives reflect the ability of fractions in certain cities to justify the division in people's minds.

\subsection{The politics and policy of division}

The final criterion reflects the divisions of the city at institutional level and administration. The latter encompasses various aspects of administrative division. However, in this context, administrative division is not only the means of subsidiarity - it also reflects geopolitical divisions typical of a specific divided city. For example, a city can be divided administratively into several districts, municipalities or counties that also include geopolitical division. Administrative Sarajevo, the capital of Bosnia- 
Herzegovina, is divided between two entities of this country - the Republic of Srpska and the Federation of Bosnia and Herzegovina. This administrative division was established by the Dayton Accords, which was signed as a means to stop the war in this country. However, the geopolitical division was provoked earlier by the events in the war and the official administrative division merely "legalized" it.

Local governments and elections are yet another aspect in which institutional division may be noticed. They are deeply rooted into democratic traditions of specific states. However, electoral results may implicate divisions even in the territorial sense. In ethnically divided societies, "ethnicity represents a fundamental political cleavage around which political interests are formed and mobilized" (Reilly, 2004: 25). Within divided cities, different preferences of electoral body can indicate commitment to political options that perpetuate divisions in the first place. On the other hand, nonfunctional local government, or government that does not control parts of its own city, indicates even stronger divisions. Laws that presume specific quotas for certain groups are another evidence in this sub-criterion.

Already mentioned institutional division as a part of this criterion, could be seen in the domains of education, transportation, or, for instance, sport. In the context of education, there are publicly funded schools or universities that exist as parallel structures and, thus, duplicate the contents of lectures. The reason for this is the conflict potential that exists between divided parts. Similar appears in public transportations. Metro, bus or tram lines in divided cities tend not to cross the borders between divided sides, no matter if those borders are physical or not. In radical situations, there are separate public companies that manage public transportations, different taxi providers, etc. In these situations, even the prices of transport can vary significantly.

Sport is a bit more complex phenomena. Normally, in most cities across the Globe there is traditional rivalry between local sport clubs. Usually, that rivalry is based upon different sports results they achieve, fans' preferences, quality of the sport they play, etc. In divided cities, traditional rivalry enhances existing geopolitical tensions between fractions in the city, which, then, use sport as a means to express differences. Consequently, this deepens the divisions further. For instance, in the Northern Irish city of Belfast the Belfast Celtic football club was dismissed in 1949 due to political situation and its strictly catholic background.

Finally, there is a criterion that could be called "the level of urbanization". It refers to visual differences in city structure and housing. Specific fractions and groups have long traditions in architecture and living styles that make the visual identity of the city district recognizable. Architectural styles are only one aspect of this criterion. Another encompasses the difference in quality of housing due to living conditions and financial status of inhabitants. Ghettoization, violent divisions and physical obstacles are phenomena that provoke divisions in the cities of tomorrow. Currently, there is a significant number of examples in Latin America - Bogota, Rio de Janeiro, etc. This criterion refers to the already mentioned concept of "dual cities" as well, introduced by Castells (1989); Sassken (1991); Van Kempen (2007); Holt-Jensen (2008) 
and many others. Due to the power-related frictions both on macro and micro scale geopolitical interpretations should seek geo-economic theories when dealing with divided cities of the future.

\section{Instead of a conclusion: The future of Divided cities}

Each classical case has to embed all parameters to be named divided city. Nevertheless, unequal globalization, fragmentation of power and its different distribution form new divisions of the future. Multispeed globalization "forms new borders on international, global level, which is evident from the different thesis on the New World Order developed after the Cold War" (Zorko, 2018:103).

In that sense, the future of divided cities is no longer monolith. Instead, new dimensions of divided cities include classical problems emphasized in this work, empowered by wealth differences of the population living in world's cities. Global border walls are not built randomly without any related patterns. Although there are barriers that could be defined as local ones, global walls are connected to one another "dividing globalized developed world from over-inhabited developing world" (Zorko, 2018:104). Such global division is reflected to local cases, especially in developing world (but not limited to it). Thus, this conclusion will briefly discuss some of the mentioned trends bearing in mind contemporary micro-geopolitical challenges that occur in the cities of North America, Australia, Latin America and Europe.

The Northern American continent is a specific multiethnic environment - historically, it would never exist as the world known today without illegal immigrants from Europe, Asia and Africa. Indigenous people living there, also referred to as Native Americans, are nowadays completely isolated from the majority of population. This paradox has a deep historical background. However, contemporary situation shows that Native Americans are still merely integrated in the US or Canadian society. Most of them live in Indian reservations or Indian reserves across the USA or Canada. A reservation/reserve presents legalized ghettos isolated from the rest of Northern American cities.

However, contemporary issues with Indian ghettos in the context of divided cities relate to inner fragmentation, isolation and division. Namely, in some reservations non-natives bought land that became a separate enclave to which reservation's laws are not applicable. This provokes significant administrative, political, legal and ethnic disturbances within specific reservations (Sutton, 2002). Thus, it is possible to rethink reservations and discuss their issues, to a limited extent, as the ones in divided cities. Such divisions, when encountering global borders, have conflict potential as well. For instance Tohono O'odham tribe culture goes back thousands of years. Their ways of life - and ceremonies - are centered on the Southwest landscape. The nation had a huge area of land that extended further north and south, in both Arizona and Mexico (Herrera, 2017). They lost the land by the Treaty of La Mesilla back in 1853 due to the solving of USA-Mexico border disputes (Ibidem). The Trump Wall might influence this sovereign nation furthermore by divisions. 
On the other side of the Globe, in Australia, there is an example of Sydney. To some extent, Sydney could be considered an ethnically divided city due to the overwhelming number of immigrants. Poulsen, Johnston and Forrest (2004), contrary to these insinuations, conducted a research to analyze if Sydney was indeed an ethnically divided city. Their results show that Sydney "appears to be moving towards being a city in which most of the population will live in areas that are classified as either non-isolated host communities, associated assimilation-pluralism communities, or mixed enclaves" (Poulsen et al., 2004:375). Instead of being a divided city, the authors of this research prefer to use a term popular with post-modern theorists - a hybrid city - "in which the ongoing processes of hybridisation are clearly reflected in the city's geography" (ibid.). Agreeing with the authors, more and more cities in the world will have some form of hybrid divisions in the future, due to the strong ongoing migration processes.

In Latin America significant income differences among the population reflect on the urban geography of big cities. In Columbia, national fragmentation of society is reflected in the country's capital Bogota (Safford and Palacios, 2002). This city is completely divided in terms of the criteria offered in this paper. However, the critical juncture that provokes division was tackled by enormous income differences between Bogota's inhabitants. Similar cases could be found in Brazil - Rio de Janeiro and Sao Paolo (Wolfensohn, 2003). In that sense, there is a possibility that future slums and ghettos within cities will be similar to existing favelas in Rio de Janeiro (Novaes, 2014).

Over the last 20 years there has been a vigorous discussion of evidence related to new and more intense social and spatial divisions within European cities. These contributions have identified "social and spatial polarization associated with globalization, deindustrialization and the increasing income inequalities arising from these" (Van Kempen and Murie, 2009:377). A new trend arises across this continent that reflects the potential of ghettoization of some of the most developed European cities. Currently, there are numerous examples of cities in which class ghettoization is evident due to several reasons.

Firstly, the European Union itself tends to be economically polarized. People from less developed member states move to certain Western European cities creating their neighborhoods that are visually different due to the difference of income. Those differences are much lighter than the ones in Latin America. Secondly, old and new migration trends bring foreigners from other continents that, then, settle in European cities. These migrants bring their cultural and religious patterns, different from local ones. Consequently, that reflects on specific cities creating ghettos reserved exclusively for specific cultures.

Finally, numerous eastern European cities have the Roma minority that fit into this pattern of ghettoization, but from the outside - the major population in certain city often ghettoizes the Roma minority. On the contrary, different cultural or class minorities form their own ghettos across Europe refusing to integrate. Unlike Australia, where good integration policies created hybrid cities in which inhabitants interact to some extent, national integration policies in Europe still fail to do so. 
Besides identifying the categorization of divisions in divided cities, this paper tackles the question of contemporary micro-geopolitical challenges in urban environment. The presented elaboration about divided cities narrows the focus on these geopolitical issues structurally. Even though many case studies appear locally and completely isolated in their nature, divided cities present a global structure or a chain of empirical facts where political, identity and power micro relations frame a geopolitical set of the above listed criteria. Thus, this paper takes the differences in divisions to establish a set of criteria applicable to the global structure of divided cities. At the same time, it emphasizes the importance of structural approach towards the micro phenomena in focus, together with some theses and guidance regarding the divisions in divided cities of the future.

\section{References}

1. Allegra, M.; Casaglia, A. and Rokem, J. (2012). The Political Geographies of Urban Polarization: A Critical Review of Research on Divided Cities. Geography Compass, 6/9: 560-574.

2. Bollens, S. A. (2011). City and Soul in Divided Societies. London: Routledge.

3. Broadbent, P. and Hake, S. (Eds.) (2010). Berlin: Divided City, 1945-1989. New York and Oxford: Berghahn Books.

4. Castells, M. (1989). The Informational City: Information Technology, Economic Restructuring and the Urban-Regional Process. Oxford: Basil Blackwell.

5. Elkins, T. H. and Hofmeister, B. (2005). Berlin. The spatial Structure of a Divided City. London/New York: Methuen.

6. Gaffkin, F. and Morrisey, M. (2011). Planning in Divided Cities: Collaborative Shaping of Contested Space. West Sussex: Blackwell Publishing Ltd.

7. Hercberg, D. and Noy, C. (2015). Mobile Cartographies and Mobilized Ideologies: the Visual Management of Jerusalem. Antipode, 47 (4): 942-962.

8. Herrera, A. (2017). President Trump, Will Native American Sovereignty Make a Difference When You Decide to Build a Wall or Not?. Global Nation, Web. https://www.pri.org/stories/2017-05-02/president-trump-will-native-americansovereignty-make-difference-when-you-decide. (Accessed 1/10/2019)

9. Holt-Jensen, A. (2008). The Dual City Theory and Deprivation in European Cities, in: Paadam, K.; Tallinn Technical University, Tallinn, Estonia / International Council for Research and Innovation in Building and Construction (CIB), W069, Housing Sociology, Rotterdam, The Netherlands (Ed.). Housing Sociology. Proceedings of the Conferences 2005 and 2004. Social Aspect of Housing Redevelopment and Housing in Ideologies/Ideologies in Housing, pp. 118 - 140. http:// www.irbnet.de/daten/iconda/CIB10436.pdf. (Accessed 6/3/2019)

10. Jonas, A. E. G. and Moisio, S. (2018). City Regionalism as Geopolitical Processes: A New Framework for Analysis. Progress in Human Geography, 42 (3): 350-370.

11. Kliot, N. and Mansfeld, Y. (1999). Case Studies of Conflict and Territorial Organization in Divided Cities. Progress in Planning, 52: 167-225.

12. Leonard, M. (2010). Parochial Geographies: Growing up in Divided Belfast. Childhood, 17 (3): 329-342. 
13. Loraux, N. (2006). The Divided City: On Memory and Forgetting in Ancient Athens. New York: Zone Books.

14. Low, S. M. (1996). The Anthropology of Cities: Imagining and Theorizing the City. Annual Review on Anthropology, 26: 383-409.

15. Michney, T. M. (2014). Segregation: a Global History of Divided Cities. Planning Perspectives, 29 (1): 131-133.

16. Miller, J. (2007). Cities Divided. Politics and Religion in English Provincial Towns, 1660 - 1722. Oxford: Oxford University Press.

17. Novaes, A. R. (2014). Favelas and the Divided City: Mapping Silences and Calculations in Rio de Janeiro's Journalistic Cartography. Social E Cultural Geography, 15 (2): 201-225.

18. O Tuathail, G.; Dalby, S. and Routledge, P. (2007). Uvod u Geopolitiku. Zagreb: Politička kultura.

19. O Tuathail, G. (1999). .Understanding Critical Geopolitics: Geopolitics and Risk Society., The Journal of Strategic Studies, 22 (2-3): 107-124.

20. O Tuathail, G. (2013). .Understanding Critical Geopolitics: Geopolitics and Risk Security., in: Gray, S. C. and Sloan, G. (Eds.). Geopolitics, Geography and Strategy. London/New York: Routledge.

21. O’Dowd, L. and McKnight, M. (2013). Religion, Violence and Cities: An Introduction. Space and Polity, 17 (3): 261-269.

22. Ohtake, R. (2008). Contradicoes da nova cidade. Revista IDE, 46: 101-103.

23. Poulsen, M.; Johnston, R. and Forrest, J. (2004). Is Sydney a Divided City Ethnically?. Australian Geographical Studies, 42 (3): 356-377.

24. Reilly, B. (2004). Democracy in Divided Societies: Electoral Engineering for Conflict Management. Cambridge: Cambridge University Press

25. Safford, F. and Palacios M. (2002). Fragmented Land, Divided Society. New York, Oxford: Oxford University Press.

26. Sassen, S. (1991). The Global City: New York, London, Tokyo. Princeton, NY: Princeton University Press.

27. Sutton, I. (2002). Cartographic Review of Indian Land Tenure and Territoriality: a Schematic Approach. American Indian Culture and Research Journal, 26 (2): 63-113.

28. Van Kempen, R. (2007). Divided Cities in the 21st Century: Challenging the Importance of Globalization. Journal of Housing and the Built Environment, 22: 13-31.

29. Van Kempen, R. and Murie, A. (2009). The New Divided City: Changing Patterns in European Cities. Tijdschrift voor Economische en Sociale Geografie - 2009, 100 (4): 377-398.

30. Wolfensohn, J. D. (2003). The Undivided City, in: Scholar, R. (Ed.). Divided Cities - The Oxford Amnesty Lectures. Oxford, New York: Oxford University Press, pp. 109-129.

31. Zorko, M. and Novak, N. (2017). Micro-geopolitical Borders of Divided Cities: the Case Study of Mostar, in: Gjurovski, M. (Ed.). Security Concepts and Policies - New Generation of Risks and Threats. Skopje: University of St. Kliment Ohridski, 95-102.

32. Zorko, M. (2018). Geopolitika i teritorijalnost. Zagreb: Jesenski \& Turk. 


\section{Marta Zorko}

Sveučilište u Zagrebu, Fakultet političkih znanosti, Hrvatska

e-mail: mzorkofpzg@gmail.com

\section{Nikola Novak}

Sveučilišni institut u Lisabonu (ISCTE-IUL), Centar za međunarodne studije, Portugal e-mail:nnkai@iscte-iul.pt

\section{Klasifikacija podijeljenih gradova: potreba za geopolitičkom perspektivom?}

\section{Sažetak}

Podijeljeni gradovi su čest fenomen u suvremenom svijetu. Svaki zaseban slučaj pod utjecajem je specifičnih, sebi svojstvenog niza faktora utjecaja i sastoji se od isto toliko različitih oblika očitovanja podjela. Ovaj rad identificira kategorizaciju podjela i uvodi kriterije koje treba uzeti u obzir prilikom istraživanja ovog fenomena. Geopolitička perspektiva služi kao instrument za zaobilaženje nedoumica pri različitim postojećim klasifikacijama podijeljenih gradova. Autori predlažu četiri skupa kriterija unutar kojih se razmatraju podijeljeni gradovi ukoliko se analiza provodi iz geopolitičke perspektive. Empirijski, podijeljeni gradovi su činjenica koja se pojavljuje u različitim manifestacijama diljem svijeta. Štoviše, većina svjetskih gradova je na neki način podijeljena, iako ih se ne može okarakterizirati podjeljenim gradovima u geopolitičkom smislu. Ovaj rad ukazuje na razlike u podjelama uzimajući u obzir geografsku, političku i identitarnu pozadinu, ali i odnose moći, uokviravajući ih u instrumentarij geopolitičkih kriterija.

Ključne riječi: mikrogeopolitika, podijeljeni gradovi, studije granica, reteritorijalizacija. 